\title{
Regional-scale mean copepod concentration indicates relative abundance of North Atlantic right whales
}

\author{
Daniel E. Pendleton ${ }^{1,2,3, *}$, Andrew J. Pershing ${ }^{2,3}$, Moira W. Brown ${ }^{4,7}$, \\ Charles A. Mayo ${ }^{4}$, Robert D. Kenney ${ }^{5}$, Nicholas R. Record ${ }^{2,3}$, Timothy V. N. Cole ${ }^{6}$ \\ ${ }^{1}$ Department of Natural Resources, Fernow Hall, Cornell University, Ithaca, New York 14853, USA \\ ${ }^{2}$ School of Marine Sciences, University of Maine, Orono, Maine 04469, USA \\ ${ }^{3}$ Gulf of Maine Research Institute, 350 Commercial St., Portland, Maine 04101, USA \\ ${ }^{4}$ Provincetown Center for Coastal Studies, 5 Holway St., Provincetown, Massachusetts 02657, USA \\ ${ }^{5}$ Graduate School of Oceanography, University of Rhode Island, Narragansett, Rhode Island 02882, USA \\ ${ }^{6}$ National Marine Fisheries Service, Northeast Fisheries Science Center, 166 Water Street, Woods Hole, Massachusetts 02543, USA
}

${ }^{7}$ Present address: New England Aquarium, Central Wharf, Boston, Massachusetts 02110, USA

\begin{abstract}
Management plans to reduce human-caused deaths of North Atlantic right whales Eubalaena glacialis depend, in part, on knowing when and where right whales are likely to be found. Local environmental conditions that influence movements of feeding right whales, such as ultradense copepod patches, are unpredictable and ephemeral. We examined the utility of using the regional-scale mean copepod concentration as an indicator of the abundance of right whales in 2 critical habitats off the northeastern coast of the United States: Cape Cod Bay and Great South Channel. Right whales are usually found in Cape Cod Bay during the late winter and early spring, and in the Great South Channel during the late spring and early summer. We found a significant positive relationship between mean concentration of the copepod Calanus finmarchicus in the western Gulf of Maine and the frequency of right whale sightings in the Great South Channel. In Cape Cod Bay we found a significant positive relationship between the mean concentration of other copepods (largely Pseudocalanus spp. and Centropages spp.) and the frequency of right whale sightings. This information could be used to further our understanding of the environmental factors that drive seasonal movement and aggregation of right whales in the Gulf of Maine, and it offers a tool to resource managers and modelers who seek to predict the movements of right whales based upon the concentration of copepods.
\end{abstract}

KEY WORDS: Eubalaena glacialis · Right whale $\cdot$ Calanus finmarchicus $\cdot$ Prey density $\cdot$ Cape Cod Bay $\cdot$ Great South Channel $\cdot$ Pseudocalanus $\cdot$ Centropages

Resale or republication not permitted without written consent of the publisher

\section{INTRODUCTION}

North Atlantic right whales Eubalaena glacialis migrate seasonally through the coastal shelf waters along the eastern coast of the USA and Canada, from southeastern Florida to the Bay of Fundy and Scotian Shelf (Winn et al. 1986). They are one of the most endangered cetacean populations (Clapham et al. 1999) and have been protected under the US Endangered
Species Act since 1973. Collisions with ships and entanglement in fishing gear are the 2 primary causes of injury and mortality of right whales attributable to human activity. The development, implementation and effectiveness of management strategies to eliminate anthropogenic mortality depend on knowing when and where right whales are likely to occur. Therefore, knowing how environmental factors influence movements of right whales would inform decision making. 
Changes in temperature, salinity, circulation and plankton abundance in the Northwest Atlantic have been linked to large-scale changes in the ocean and atmosphere (Durbin et al. 2000, Greene \& Pershing 2000, MERCINA 2001, Pershing et al. 2005). The variability in abundance of the primary prey of right whales, the copepod Calanus finmarchicus, in the Gulf of Maine explains a large proportion of the variability in the number of right whale births (Greene \& Pershing 2004). On a finer scale, changes in circulation influence where whales feed (Kenney et al. 1995). Given this, a better understanding of physical and biological oceanographic processes can aid conservation.

Direct observations of right whales feeding on dense aggregations of Calanus finmarchicus have been documented in several studies (Watkins \& Schevill 1976, Wishner et al. 1988, Mayo \& Marx 1990, Beardsley et al. 1996), and indirect evidence of right whales feeding at depth on this copepod has been inferred from simultaneous surface observations, water-column sampling (Murison \& Gaskin 1989) and dive records (Baumgartner \& Mate 2003). The diet of right whales, however, is not monospecific; it includes mesozooplankton such as Pseudocalanus spp., Centropages spp., larval barnacles and possibly euphausiids (Watkins \& Schevill 1976, Murison \& Gaskin 1989, Mayo \& Marx 1990).

A leading hypothesis to explain right whale movement posits that whales forage nomadically, moving through the Gulf of Maine and adjoining areas in response to changes in the zooplankton prey resource (Gaskin 1982, Kenney et al. 2001). Standard zooplankton sampling programs do a good job of measuring copepod concentrations at the regional-scale (10 to 100 s of kilometers), but they do not adequately resolve the ultra-dense concentrations of copepods, at the scale of 1 to 10 s of meters, that right whales feed upon (Kenney et al. 1986a). Baumgartner et al. (2007) suggested that the regional-scale copepod concentration is not proportional to right whale abundance. In the present study we tested the hypothesis that regional-scale mean copepod concentration is an indicator of the number of right whales in a region and, by implication, the number and quality of ultra-dense copepod patches that right whales are known to consume. Our hypothesis stems from a simple conceptual model: if no copepods are present in a region, no copepod patches will form. If many copepods are present in a region, many patches will form.
Herein we report on a comparison of datasets representing the densities of copepods and sighting frequencies of right whales in 2 US right whale critical habitats: Cape Cod Bay, a shallow coastal bay that is protected by land on 3 sides, and the Great South Channel, a region at the southern end of the Gulf of Maine between Cape Cod and Georges Bank (Fig. 1). Knowing the degree of association between the regional-scale mean copepod concentration and right whale abundance could offer managers a tool for assessing the likelihood of right whale occurrence. This information could also guide inferences drawn from model simulations of regional-scale copepod concentration (e.g. Lynch et al. 1998).

\section{MATERIALS AND METHODS}

We focused on 2 right whale critical habitats: Cape Cod Bay and the Great South Channel. In each habitat area we compared the mean copepod concentration with an effort-corrected index of right whale abundance, sightings per unit effort (SPUE). Copepod measurements came from 3 sources: the Gulf of Maine continuous plankton recorder (CPR), vessel-based net

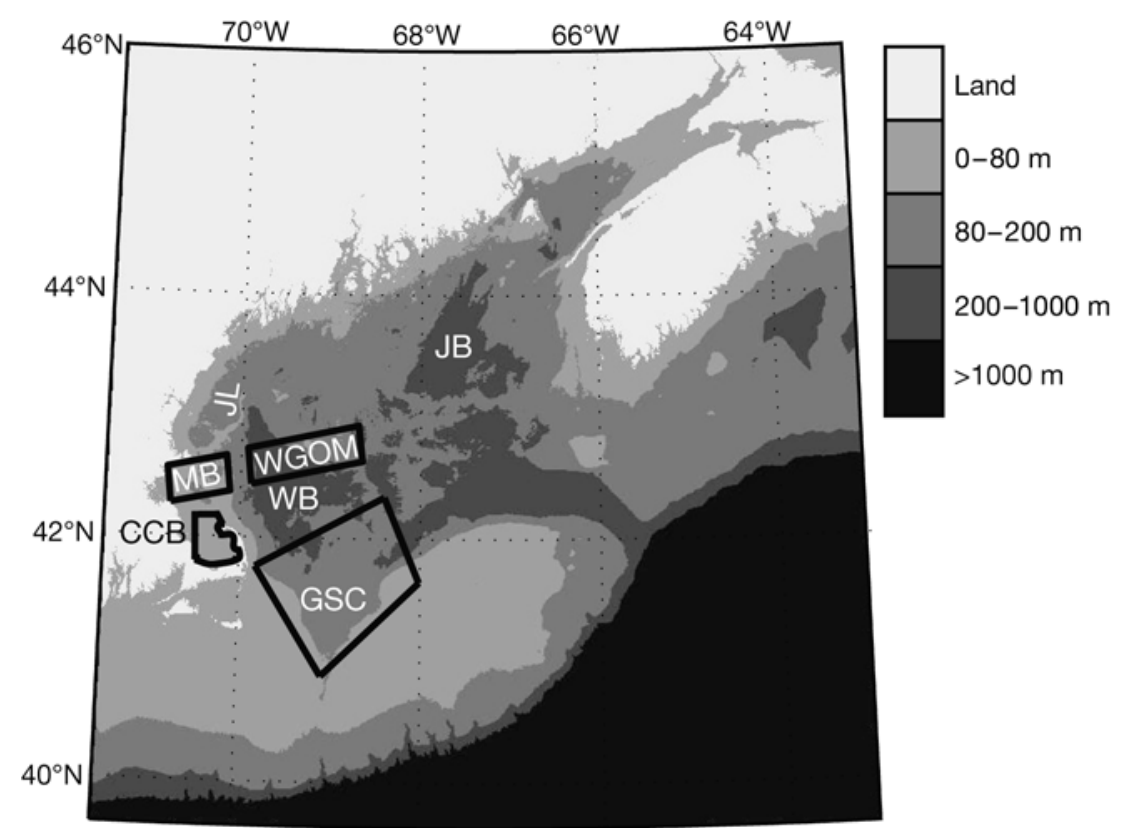

Fig. 1. The Gulf of Maine, the northeastern coast of the USA and the southeastern coast of Canada. Bathymetric contours at 0, 80, 200 and $1000 \mathrm{~m}$ are depicted with shading. Cape Cod Bay (CCB) right whale critical habitat and the Great South Channel (GSC) right whale critical habitat expanded by $30 \%$ are outlined, as are the Massachusetts Bay (MB) and the western Gulf of Maine (WGOM) sections of the Gulf of Maine continuous plankton recorder (CPR) survey. JL: Jeffrey's Ledge; JB: Jordan Basin; WB: Wilkinson Basin. All 1999-2006 CPR samples came from the MB and WGOM regions. A few samples prior to 1999 were collected as far north as $43^{\circ} 8.2^{\prime} \mathrm{N}$ and as far south as $42^{\circ} 14.3^{\prime} \mathrm{N}$ 
sampling in Cape Cod Bay by the Provincetown Center for Coastal Studies (PCCS), and vessel-based net sampling in the Great South Channel by the National Marine Fisheries Service's (NMFS) Marine Resources Monitoring, Assessment and Prediction program (MARMAP). Right whale SPUE values were computed from survey data in the North Atlantic Right Whale Consortium (NARWC) database.

Copepod sampling. The CPR is an instrument that is towed behind ships of opportunity at a depth of about $10 \mathrm{~m}$ (Warner \& Hays 1994). Organisms are captured on a continuous silk mesh as seawater passes through the instrument body. The Gulf of Maine CPR survey collects samples along a transect from Boston, Massachusetts to Yarmouth, Nova Scotia (Jossi \& Goulet 1993). We analyzed copepod samples from 2 segments or tracts of the CPR transect, upstream of our study regions (Fig. 1). Calanus finmarchicus progress through 13 stages: egg, 6 naupliar stages and 5 copepodid stages (C1-C5) before reaching adulthood (C6). Stage C5-C6 C. finmarchicus and 'other copepods' (C6 Pseudocalanus spp. and Centropages typicus) from the CPR tract in Massachusetts Bay and the western Gulf of Maine were used in our analysis of Cape Cod Bay and the Great South Channel, respectively. Because the CPR is towed without respect to time of day at a constant depth, diel vertical migration could bias estimates of $C$. finmarchicus concentration. To test for this we performed an unpaired $t$-test on $\log _{10}(x+1)$ transformed, day versus night, data (Kane 2005). No significant difference was found $(p=0.34)$ indicating that diel vertical migration would not adversely impact our results.

Copepod samples were collected by the Provincetown Center for Coastal Studies (PCCS) within Cape Cod Bay approximately weekly from late December to late May from 1999 to 2006. On each cruise 8 to 10 fixed stations were sampled; however, weather conditions sometimes reduced the number of stations visited. All sampling took place during daylight hours. Occasionally, sampling cruises were conducted at other times of the year. Typically, at each station a $30 \mathrm{~cm}$ diameter, $333 \mu \mathrm{m}$ mesh net was towed at a depth of about $1 \mathrm{~m}$ and at a speed of $1.5 \mathrm{~m} \mathrm{~s}^{-1}$ for $5 \mathrm{~min}$, following the methods of Mayo et al. (2004). The $333 \mu \mathrm{m}$ mesh size was chosen to mimic the particle capture properties of right whale baleen (Mayo et al. 2001). From this dataset we defined 2 quantities: (1) the concentration of Calanus finmarchicus, and (2) the concentration of 'other copepods.' Strictly, this second quantity represents the mean concentration of all organisms captured that were not C. finmarchicus, but it is primarily comprised of Pseudocalanus spp. and Centropages spp. (Mayo et al. 2004) Beginning in 2003, surface tows were augmented with oblique tows.
To test for potential bias introduced by surface-only sampling, we compared mean concentrations from surface and oblique tows within 28 d intervals (as was done for our interannual analysis, see below) from 2003 to 2006. There was a significant linear relationship between $C$. finmarchicus measured by oblique versus surface tows $\left(\mathrm{r}^{2}=0.88, \mathrm{p}<0.001\right)$, and between other copepods measured by oblique versus surface tows $\left(\mathrm{r}^{2}=0.59, \mathrm{p}<0.001\right)$. These statistics indicated that the vertical distribution of copepods would not impact our results. We elected to use the surface rather than the oblique tow dataset because it spanned $8 \mathrm{yr}$ (1999-2006) rather than 4 yr.

During the MARMAP program (Sibunka \& Silverman 1984, 1989, Meise \& O'Reilly 1996) zooplankton were collected in the Gulf of Maine by double oblique tows with a $333 \mu \mathrm{m}$ mesh net attached to a bongo sampler (Posgay \& Marak 1980). Tows were made from the surface to $5 \mathrm{~m}$ above the bottom and back to the surface, but did not exceed a depth of $200 \mathrm{~m}$. For the purposes of the present study, we defined Great South Channel to include the Great South Channel right whale critical habitat expanded uniformly by $30 \%$. The vertices of this polygon are $40^{\circ} 50.8^{\prime} \mathrm{N}$, $69^{\circ} 07.2^{\prime} \mathrm{W}_{;} \quad 41^{\circ} 44.5^{\prime} \mathrm{N}, \quad 69^{\circ} 51.8^{\prime} \mathrm{W} ; \quad 42^{\circ} 19.0^{\prime} \mathrm{N}$, $68^{\circ} 26.9^{\prime} \mathrm{W} ; 41^{\circ} 37.4^{\prime} \mathrm{N}, 68^{\circ} 03.5^{\prime} \mathrm{W}$ (Fig. 1). We extracted archived MARMAP C5-6 Calanus finmarchicus data collected within the Great South Channel for use in the present study.

Right whales. All analyses were accomplished using data extracted from the NARWC database (Kenney 2001, Right Whale Consortium 2007). Included in our dataset is survey and right whale sighting information from numerous programs. The sources were the Cetacean and Turtle Assessment Program (CETAP) from 1978 to 1982 (CETAP 1982), a set of contract surveys by the University of Rhode Island (URI) from 1984 to 1993 (Winn et al. 1985, Kenney et al. 1986b, Kenney \& Winn 1986a, 1987, Kenney 2001), the South Channel Ocean Productivity Experiment (SCOPEX) program from 1988 to 1989 (Kenney \& Wishner 1995), aerial right whale surveys by the NMFS Northeast Regional Office and Northeast Fisheries Science Center (NEFSC) from 1998 to 2006 (Cole et al. 2007), aerial surveys conducted by PCCS from 1998 to 2006 (Brown et al. 2007), other aerial and shipboard surveys by NMFS between 1991 and 2002, and smaller survey datasets contributed by several NARWC member organizations (PCCS, New England Aquarium, International Fund for Animal Welfare, Whale Center of New England, and Associated Scientists at Woods Hole).

The dataset we used included 2 data types. First, line-transect aerial surveys were conducted as part of CETAP, SCOPEX and URI's Great South Channel 
studies to derive estimates of density and abundance of species within defined areas (which differed within and between programs). These surveys were conducted under rigorous criteria by highly trained observers from one of 2 aircraft, and were designed to represent statistically random samples of the area. Second, platforms-of-opportunity (POP) surveys were those where the observers collected complete records of aircraft or ship tracks and associated sighting conditions, but where the surveys were not sufficiently standardized to use for line-transect methods. Data from line-transect surveys conducted by NEFSC are archived in the NARWC database in the POP format.

The pattern of survey coverage (or 'effort') can bias the interpretation of raw sighting data. One method to overcome this potential bias is to quantify sighting effort, and then to correct sighting frequencies for differences in effort, producing an index termed 'sightings per unit effort' (SPUE). The units are numbers of whales sighted per unit length of survey track. To standardize the SPUE data even further, the data may be limited to only a subset of the survey tracklines which meet some defined criteria for 'acceptability' (see below). If the SPUE values are computed for consistent spatial units, they can be mapped to show effortcorrected distribution patterns. SPUE values also can be statistically compared across areas, seasons, years, etc. Development of this method began during CETAP (1982), and it has been used in a variety of analyses (Kenney \& Winn 1986b, Winn et al. 1986, Kenney 1990, Hain et al. 1992, Shoop \& Kenney 1992, Kraus et al. 1993, DoN 2005, Pittman et al. 2006).

All available line-transect aerial and POP aerial and shipboard survey data from 1999 to 2006 from the region encompassing Cape Cod Bay, and from 1978 to 2006 from the region encompassing the Great South Channel, were extracted from the NARWC database and combined to quantify sampling effort and derive right whale SPUE values. Only trackline segments completed with at least one observer on watch, clear visibility of at least 2 nautical miles $(3.7 \mathrm{~km})$, sea state of Beaufort 3 or lower, and altitude of less than $366 \mathrm{~m}$ $(1200 \mathrm{ft})$ for aerial surveys were included as acceptable effort. The entire area was partitioned spatially into a grid of cells measuring 5 minutes of latitude $(9.3 \mathrm{~km})$ by 5 minutes of longitude $(6.8-7.0 \mathrm{~km})$ and temporally by $14 \mathrm{~d}$ periods.

Effort was quantified as the length of survey track completed within the spatial and temporal confines of the grid cells. All acceptable effort within each grid cell and time period was summed. Grid cells in which there was less than $2.5 \mathrm{~km}$ of survey track completed were excluded from our analysis as inadequately sampled. Similarly, only right whales sighted during acceptable effort were included and summed within each cell and period. The effort threshold value of $2.5 \mathrm{~km}$ was chosen after experimenting with several threshold values between 0 and $6.8 \mathrm{~km}$ (the east-west distance across a $5 \times 5$ minute cell). This threshold appeared to remove the most outliers without drastically reducing the number of records available for analysis. Finally, the number of animals sighted was divided by effort to generate the SPUE index, in units of animals sighted per $1000 \mathrm{~km}$ of valid effort. In the text of this manuscript we refer to 'right whale SPUE'. In the figures and where numeric values are cited, we used 'right whales per $1000 \mathrm{~km}$ ' or 'whales per $1000 \mathrm{~km}$ '.

We selected geographical subsets of the SPUE dataset for our analysis. For Cape Cod Bay our data included the area enclosed by Cape Cod Bay to the northern extent of the Cape Cod Bay right whale critical habitat (defined by the inner coastline of the Bay and $42^{\circ} 04.8^{\prime} \mathrm{N}, 70^{\circ} 10.0^{\prime} \mathrm{W}_{i} 42^{\circ} 12.0^{\prime} \mathrm{N}, 70^{\circ} 15.0^{\prime} \mathrm{W}$; $42^{\circ} 12.0^{\prime} \mathrm{N}, 70^{\circ} 30.0^{\prime} \mathrm{W}_{;} 41^{\circ} 46.8^{\prime} \mathrm{N}, 70^{\circ} 30.0^{\prime} \mathrm{W}$ ) (Fig. 1). For the Great South Channel the SPUE data subset consisted of the area within a $30 \%$ uniform dilation of the Great South Channel right whale critical habitat (described above).

Data analysis. Copepod concentration and right whale SPUE values reported in the present study represent the mean concentration, or SPUE value, within each habitat area over the specified time interval. Copepod concentrations were log-transformed prior to analysis and are reported as $\log _{10}$ (no. ind. $\mathrm{m}^{-3}+1$ ).

We first analyzed seasonally expected changes in copepod concentration and right whale SPUE in each habitat area by computing climatological time series of copepod concentration and right whale SPUE values. A climatology is a 1-yr time series that is produced by averaging all measurements within predefined intervals of time across all years. The resultant time series represents conditions in a 'typical' year. In the present study we used $14 \mathrm{~d}$ intervals to compute climatological values. Thus, each point in the climatology represents the mean copepod concentration or right whale SPUE value within the habitat area and within each $14 \mathrm{~d}$ period. Climatologies were computed from each dataset using data from the following years: (1) CPRderived Calanus finmarchicus and other copepods from 1961 to 2006, (2) MARMAP-derived C. finmarchicus from 1977 to 1997, (3) PCCS-derived C. finmarchicus and other copepods from 1999 to 2006, and (4) NARWC right whale SPUE from 1999 to 2006 and 1978 to 2006 in Cape Cod Bay and the Great South Channel, respectively (Table 1 ).

Next, we analyzed interannual changes in mean copepod concentration and right whale SPUE in each habitat area. The time frame for this analysis (1999 to 2006) was chosen to coincide with increased data collec- 
tion efforts that began in 1999 and have been sustained.

In Cape Cod Bay we restricted our interannual comparison to the first 5 mo of each year, the time period of consistent sampling by PCCS. Yearly time series of Calanus finmarchicus, other copepods and right whale SPUE were computed using $14 \mathrm{~d}$ periods. For our statistical analysis, linear regression was used to determine if there was a significant relationship between mean copepod concentration and right whale SPUE within $28 \mathrm{~d}$ periods. This longer time period was used because timing of copepod sampling and right whale surveys was not synchronized, and some $14 \mathrm{~d}$ periods contained relatively small amounts of data.

For our interannual comparison of Calanus finmarchicus concentration and right whale SPUE in the Great South Channel habitat area, we plotted yearly time series of CPR-derived $C$. finmarchicus and other copepod concentration from the western Gulf of Maine using $56 \mathrm{~d}$ periods ( 2 consecutive $28 \mathrm{~d}$ periods), and yearly time series of right whale SPUE using $28 \mathrm{~d}$ periods. The $56 \mathrm{~d}$ time period was necessary because there are only few records each month from the CPR. For our statistical analysis, linear regression was used to determine if there was a significant relationship between mean $C$. finmarchicus and other copepod concentration and mean right whale SPUE within trimesters from 1999 to 2006. Trimesters were defined by the following intervals: 1 January-22 April (trimester 1, $112 \mathrm{~d}$ and $113 \mathrm{~d}$ during leap years), 23 April-12 August (trimester 2, $112 \mathrm{~d}$ ), and 13 August-31 December (trimester 3, $141 \mathrm{~d}$ ). Trimester 3 is longer than trimesters 1 and 2 because a year cannot be equally divided into the $28 \mathrm{~d}$ periods that we found necessary to standardize our analysis. We performed an identical 1999 to 2006 trimester analysis between CPR-derived C. finmarchicus concentration from Massachusetts Bay and right whale SPUE from the Great South Channel.

The temporal resolution of MARMAP sampling after 1987 was too sparse to use in our interannual analysis. Fortunately, the western Gulf of Maine tract of the CPR is directly upstream of the Great South Channel, and the regions are oceanographically connected by geographic proximity and local circulation patterns (Chen et al. 1995). We found a significant correlation $\left(\mathrm{r}^{2}=0.26\right.$, $\mathrm{p}<0.001, \mathrm{n}=63$ ) between CPR- and MARMAP-derived Calanus finmarchicus concentration from corresponding trimesters. For these reasons we feel justified using C. finmarchicus measurements from the western Gulf of Maine tract of the CPR as a proxy for the C. finmarchicus measurements in the Great South Channel.

The copepod sampling methodology was consistent within each region. Therefore, comparison of relative copepod concentrations within a region and across time is appropriate, but direct comparison of values between regions is not. Right whale SPUE values for both regions came from the same database, but we caution readers against making direct comparisons of SPUE values between regions.

Due to the small number of data points used in the linear regressions, correlation coefficients and statistical significance were sensitive to each data point. For this reason, we consider relationships with $p$-values near 0.15 to be meaningful; however, our criteria for statistical significance is $\mathrm{p}<0.05$.

\section{RESULTS}

\section{Cape Cod Bay: climatological patterns}

Climatological Calanus finmarchicus concentration in Cape Cod Bay (Fig. 2a) rises from a very low concentration in January to a local maximum of $10^{2.4}$ ind. $\mathrm{m}^{-3}$ at the end of April. C. finmarchicus concentration during May and June varies in excess of one order of magnitude. Maximum $C$. finmarchicus concentration of $10^{3}$ ind. $\mathrm{m}^{-3}$ is reached in late June. From mid-July to early September C. finmarchicus concentration is less than $10^{0.5}$ ind $\mathrm{m}^{-3}$, on par with the concentration measured during January. From October to mid-November there is an increase in C. finmarchicus concentration of almost 1.5 orders of magnitude. The concentration in December is less than $10^{0.2}$ ind. $\mathrm{m}^{-3}$ and is on par with the January concentration. There are no C. finmarchicus or other 
copepod measurements available in early July, midSeptember or late November.

Unlike Calanus finmarchicus, the mean concentration of other copepods in January is near the maximum yearly value. The only other time that concentration exceeds $10^{3}$ ind. $\mathrm{m}^{-3}$ is during December. From January to May the concentration of other copepods declines steadily, by almost an order of magnitude, from $10^{3.1}$ to $10^{2.2}$ ind. $\mathrm{m}^{-3}$. The concentration then increases and remains relatively high $\left(>10^{2}\right.$ ind. $\mathrm{m}^{-3}$ ) from June through August, when the concentration appears to decline substantially before rebounding to levels in excess of $10^{2}$ ind. $\mathrm{m}^{-3}$.

The CPR measurements of Calanus finmarchicus (Fig. 2b) from the Massachusetts Bay tract of the CPR, north of Cape Cod Bay, are generally higher than the measurements of $C$. finmarchicus within Cape Cod Bay, though a direct comparison of concentrations from the CPR and net tows is problematic. Massachusetts Bay CPR C. finmarchicus concentration does not fall below $10^{1.3}$ ind. $\mathrm{m}^{-3}$, and only exceeds $10^{3}$ ind. $\mathrm{m}^{-3}$ dur-


Fig. 2. Calanus finmarchicus, other copepods (Pseudocalanus spp. and Centropages spp.) and Eubalaena glacialis. Climatological time series of (a) $C$. finmarchicus $(\Delta)$ and other copepods $(\square)$ from surface tows in Cape Cod Bay (1999-2006), (b) C. finmarchicus (*) from the Massachusetts Bay tract of the CPR (1961-2006), and (c) right whale SPUE (whales per $1000 \mathrm{~km}$ of survey effort) (O) in Cape Cod Bay (1999-2006). Each point represents the mean \pm 1 SE for a $14 \mathrm{~d}$ period ing 2 periods, early July and early August. The maximum springtime $C$. finmarchicus concentration occurs at the beginning of April. Subsequent to this, C. finmarchicus concentration rises and falls in a pattern reminiscent of, but less pronounced than, C. finmarchicus in Cape Cod Bay (Fig. 2a). From this point on in Massachusetts Bay, C. finmarchicus concentration declines steadily, with the exception of a brief increase in concentration during October. During November nd December the concentration is relatively constant.

Right whale SPUE is near zero whales per $1000 \mathrm{~km}$ in January (Fig. 2c), but increases to its maximum value of 16.5 whales per $1000 \mathrm{~km}$ in early April. Right whale SPUE then decreases nearly twice as fast as it increased. Right whale SPUE is at or near zero whales per $1000 \mathrm{~km}$ from late June to early December.

The rise and fall in right whale SPUE is not reflected in copepod data, however there are some similarities. Calanus finmarchicus concentration and right whale SPUE measured inside Cape Cod Bay both rise rapidly for about the first 3 mo of the year. In early April right whale SPUE declines rapidly, while $C$. finmarchicus concentration continues to rise. The concentration of other copepods declines throughout the entire rise and fall in right whale SPUE, January through May. In mid-May, the concentration of other copepods and right whale SPUE are at their minimum values for the first 5 mo of the year. The springtime local maximum in C. finmarchicus concentration from the Massachusetts Bay tract of the CPR cooccurs with the yearly right whale SPUE maximum.

\section{Great South Channel: climatological patterns}

In the Great South Channel, MARMAPderived Calanus finmarchicus concentration increases steadily from January through March (Fig. 3a). There is an abrupt increase in C. finmarchicus concentration during April, after which the concentration remains high until mid-June. The maximum concentration $\left(10^{2.6}\right.$ ind. $\mathrm{m}^{-3}$ ) occurs in mid-May. After late June, C. finmarchicus concentration falls back to pre-April levels. Following this reduction, there is subtle evidence of a second highconcentration period during August and September. The C. finmarchicus concentration from mid-October through December is relatively low. 
From January to late March the CPR-derived Calanus finmarchicus concentration is relatively constant, with slight increases in concentration during late February and early March. The mean value during this period is $10^{2.5}$ ind. $\mathrm{m}^{-3}$. C. finmarchicus concentration then increases gradually to the maximum value of $10^{3.6}$ ind. $\mathrm{m}^{-3}$ in late May. This high concentration is sustained for about one month. There is a steady decline in concentration from mid-June to the end of August, when the minimum yearly concentration of $10^{1.5}$ ind. $\mathrm{m}^{-3}$ is reached. C. finmarchicus concentration quickly rebounds to values on par with those exhibited in mid-August, but then declines and is relatively low throughout November and December.

The concentration of other copepods from the CPR (Fig. 3a) is inverted from that of Calanus finmarchicus - it is relatively low for the first half of the year, and relatively high for the latter half of the year. A similar pattern was noted by Pershing et al.
(2005). The concentration declines from mid-January through February, and until mid-June a relatively low level is sustained $\left(\right.$ mean $=10^{0.7}$ ind $\mathrm{m}^{-3}$ ). The concentration then rises rapidly, 3 orders of magnitude over $2 \mathrm{mo}$, to the yearly maximum of $10^{3.9}$ ind. $\mathrm{m}^{-3}$, and remains high until a rapid decline begins in November.

The MARMAP and western Gulf of Maine CPR climatological Calanus finmarchicus time series show similar patterns in abundance through time. The CPR C. finmarchicus concentration appears to lag behind that of MARMAP by 2 to $4 \mathrm{wk}$. Both time series show a prominent and a subtle high-concentration period: a prominent peak occurs in early May and in the first half of June, and a less obvious peak occurs in late July and in mid-September, for the MARMAP and CPR time series, respectively. Additionally, the CPR time series shows a subtle peak in late February and early March that cannot be seen in the MARMAP time series.

As in Cape Cod Bay, right whale SPUE in the Great South Channel is seasonal (Fig. 3b). During January and February right whales are sighted very infrequently in the habitat area, indicated by near zero SPUE values. In March, right whale SPUE begins to steadily increase, and during the $14 \mathrm{~d}$ period in early May there is a $67 \%$ increase in SPUE. The highest SPUE value of the year (18.8 whales per $1000 \mathrm{~km}$ ) occurs in late May. This maximum value co-occurs with the maximum CPR Calanus finmarchicus concentration, and occurs 2 wk after the maximum MARMAP C. finmarchicus concentration. Right whale SPUE decreases from mid-June through July, and from early August to the end of the year SPUE is at or near zero whales per $1000 \mathrm{~km}$.

There is a strong positive relationship between the climatological time series of Calanus finmarchicus and right whale SPUE during the 'right whale season' of March through July in the Great South Channel (Fig. 4). During this time period, the relationship between MARMAP C. finmarchicus concentration and right whale SPUE is significant $\left(\mathrm{r}^{2}=0.65, \mathrm{p}<0.01\right)$, while the relationship between climatological CPR C. finmarchicus concentration and right whale SPUE is weaker $\left(\mathrm{r}^{2}=0.40\right.$, $p=0.05)$. These relationships, along with the correlation between MARMAP and CPR C. finmarchicus concentrations (see above), support the use of mean $C$. finmarchicus concentration from the western
Fig. 3. Calanus finmarchicus, other copepods (Pseudocalanus spp. and Centropages spp.) and Eubalaena glacialis. Climatological time series of (a) Calanus (*) and other copepods $(\diamond)$ from the western Gulf of Maine tract of the CPR (1961-2006), and Calanus $(\Delta)$ from the Marine Resources Monitoring, Assessment and Prediction (MARMAP) program in the Great South Channel (1977-1997), and (b) right whale SPUE (whales per $1000 \mathrm{~km}$ of survey effort) (O) in the Great South Channel (1978-2006). Each point represents the mean $\pm 1 \mathrm{SE}$ for a $14 \mathrm{~d}$ period 




Fig. 4. Calanus finmarchicus and Eubalaena glacialis. March through July correlation of climatological right whale SPUE (whales per $1000 \mathrm{~km}$ of survey effort) in the Great South Channel (1978-2006) versus (a) C. finmarchicus from the western Gulf of Maine tract of the CPR (1961-2006) and (b) C. finmarchicus from MARMAP surveys in the Great South Channel (1977-1997). Each point represents the March through July climatological mean

Gulf of Maine tract of the CPR as a proxy for mean $C$. finmarchicus concentration in the Great South Channel.

\section{Cape Cod Bay: interannual patterns}

During January to February from 1999 to 2006, the range of values spanned by the mean concentration of Calanus finmarchicus was less than one order of magnitude. Beginning in March, yearly C. finmarchicus time series diverge from one another and years with high concentrations can be visually separated from years with low concentrations (Fig. 5a). C. finmarchicus concentration in 1999, 2001 and 2005 was consistently high through March and April. A comparably high concentration was reached in 2000 and 2003, but during these years the springtime increase in $C$. finmarchicus concentration lagged by 2 to 4 wk. C. finmarchicus concentration declined in May during all years except 2002, when the concentration continued to increase throughout May. Because sampling stopped early in some years, there were no C. finmarchicus or other copepod data available after the first week of May in 1999, 2000 and 2006.

From 1999 to 2002, the range of values spanned by the mean concentration of other copepods was less than one order of magnitude, with the exception of a lower concentration in April 2002. The concentration of other copepods from 2003 to 2006 declined faster and was more variable than the concentration from 1999 to 2002. Notable examples of this are the years 2003 and 2004. By May 2003, Calanus finmarchicus concentration was 1.5 orders of magnitude lower than it was in January 2003. The concentration in early March 2003 was the second lowest for that year, and 6 wk later the concentration was at its peak value for that year. The greatest decline in concentration, over 2 orders of magnitude, occurred from January to May 2004. From mid-February though March 2004, the concentration of other copepods was relatively stable at a value above the 2003 to 2006 average. De Lorenzo Costa et al. (2006) reported similar patterns in their monthly analysis of copepod concentration in Cape Cod Bay from 2000 to 2003.

In general, right whale SPUE was higher from 1999 to 2002 than it was from 2003 to 2006 (Fig. 5c). In 2000, right whale SPUE was unusually high in Cape Cod Bay; SPUE peaked from mid-March to mid-April, and declined to zero whales per $1000 \mathrm{~km}$ by the end of April. During 2002, right whale SPUE peaked in midFebruary, 6 to 8 wk before copepod concentration was expected to peak (Fig. 2b). The years 2003 to 2006 exhibited very similar patterns: a slow increase in right whale SPUE from the beginning of the year until the maximum was reached in April, after which right whale SPUE declined in May. Of the latter $4 \mathrm{yr}_{\text {, the }}$ highest right whale SPUE was found in 2003, and it cooccurred with the 2003-2006 maximum concentration of Calanus finmarchicus and other copepods.

Broadly speaking, Calanus finmarchicus concentration was lower from 1999 to 2002 than from 2003 to 2006. The opposite pattern was exhibited in the concentration of other copepods and right whale SPUE, which were both higher from 1999 to 2002 than from 2003 to 2006.

During January, February and most of March, a generally negative relationship can be seen between regionwide Calanus finmarchicus concentration and right whale SPUE in Cape Cod Bay (Fig. 6a). The apparent negative relationship was strongest in January $\left(\mathrm{r}^{2}=0.37\right.$, $\mathrm{p}=0.108$; Table 2), and was weaker in February and March. The relationship between $C$. finmarchicus concentration and right whale SPUE appears to have switched from negative to positive in the period of late March to late April. During this time of year in Cape Cod Bay, C. finmarchicus typically becomes a larger propor- 
tion of the copepod assemblage (Fig. 2a), while right whales are sighted with increasing frequency (Fig. 2c).

The relationship between the mean concentration of other copepods and right whale SPUE in Cape Cod Bay was generally positive (Fig. 6b). During January there was no apparent relationship, but in each of the following 2 time periods (spanning 29 January25 March) a positive, but insignificant, relationship can be seen between the concentration of other copepods and right whale SPUE. During the 'right whale season,' when right whales are expected in high numbers (26 March-22 April) in Cape Cod Bay, there was a significant association between the concentration of
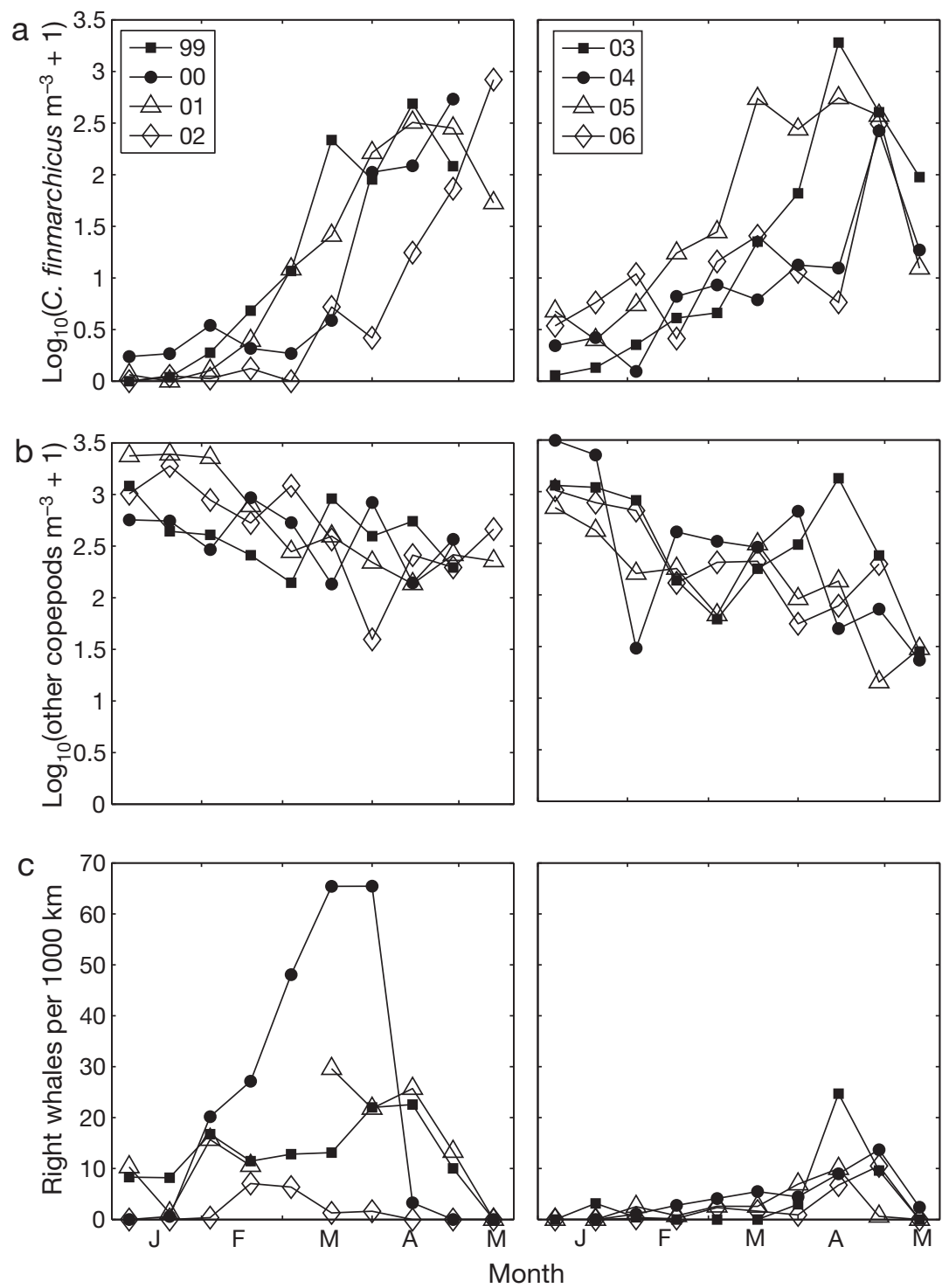

Fig. 5. Calanus finmarchicus, other copepods (Pseudocalanus spp. and Centropages spp.) and Eubalaena glacialis. Yearly time series (1999-2006) from Cape Cod Bay of (a) C. finmarchicus and (b) other copepods collected by surface tow, and (c) right whale SPUE (whales per $1000 \mathrm{~km}$ of survey effort). Each point represents the mean over a $14 \mathrm{~d}$ period other copepods and right whale SPUE $\left(\mathrm{r}^{2}=0.53, \mathrm{p}<\right.$ 0.05, Table 2). There was no discernable relationship between the concentration of other copepods and right whale SPUE in the subsequent $28 \mathrm{~d}$ period, from 23 April to 20 May.

\section{Great South Channel: interannual patterns}

Western Gulf of Maine Calanus finmarchicus concentration from 1999 to 2002 was generally low with high variability, while from 2003 to 2006 the concentration was generally high with low variability (Fig. 7a). C. finmarchicus concentration in 2000 was particularly low in the latter half of the year. The year 2001 was unique in that $C$. finmarchicus increased in the latter half of the year. In 2003 and 2004 the concentration of $C$. finmarchicus rose to near-maximum concentrations about 2 mo before the maximum was reached in mid-May. The years 2005 and 2006 exhibited a different pattern: C. finmarchicus concentration rose at about the same rate from January until the yearly maximum concentration was reached in mid-May. Concentration in the latter half of 2005 was the lowest of any year except 2000. There were no data available for mid-May of 1999 or 2001, when the maximum $C$. finmarchicus concentration typically occurred.

The early year concentration of other copepods from the western Gulf of Maine CPR (Fig. 7b) tract was generally high from 1999 to 2002, and was generally low from 2003 to 2006 . With the exception of the second 56 d period, concentrations in 2000 were unusually high. In 1999 and 2000, the end-year decline in concentration, seen in all other years, was not observed. Concentrations from 2003 to 2006 were bimodal, with peaks in concentration early and late in the year. Within all of these years, except 2004, a difference of at least one order of magnitude can be seen between the early and late peaks in concentration.

The yearly right whale SPUE time series (Fig. 7c) from the Great South Channel shows a great deal of variation from the climatology (Fig. 3b). Right whales were usually first sighted in the Great South Channel during March (Fig. 7c). The maximum right whale SPUE was typically reached during May or June, and by August or September right whale SPUE in 
the Great South Channel was at or near zero. Right whale SPUE was generally lower from 1999 to 2001 than in the following years, and particularly low SPUE values were found in 1999 and 2000. Right whale SPUE from 2003 to 2006 was highly variable within years. In March of 2003, right whale SPUE was very high (Fig. 7c inset), but subsequently declined to more typical levels. The highest right whale SPUE value, aside from the outlier in March of 2003, was recorded in late May and early June 2004. In 2005 there were 2 right whale SPUE maxima: a local maximum during April, followed by a decline, and then the yearly maximum value in July. This pattern was also observed in 2006, but the time series was shifted back by about one month, so that there was a local maximum in March, followed by a decline, and then the yearly maximum right whale SPUE in June. A small number of survey flights were directed toward the location of suspected aggregations of whales. Records from these flights are not easily identifiable in the NARWC database, and it is possible that the peculiar SPUE peaks seen in March are due to such flights.

Right whale SPUE was usually higher in the Great South Channel when the Calanus finmarchicus concentration was high in the western Gulf of Maine (Fig. 8a). During trimester 1 (January through late April) there was a weak positive association between C. finmarchicus concentration and right whale SPUE. During trimester 2 (late April to mid-August) the association was significant and positive $\left(r^{2}=0.54, p<0.05\right)$. In trimester 3 (mid-August through December) there was no detectable relationship between $C$. finmarchicus concentration and right whale SPUE. In addition to the correlations, a more general relationship holds: right whale SPUE was relatively low when C. finmarchicus concentration was low, and when right whale SPUE was high in the Channel, C. finmarchicus concentration was high. No relationship was found



Fig. 6. Calanus finmarchicus, other copepods (Pseudocalanus spp. and Centropages spp.) and Eubalaena glacialis. Cape Cod Bay mean copepod concentration from surface tows versus right whale SPUE (whales per $1000 \mathrm{~km}$ of survey effort) within the first five 28 d periods from 1999 to 2006. (a) C. finmarchicus and (b) other copepods plotted against right whale SPUE. Lines are linear least squares fits: $(-) \mathrm{p}<0.05 ;(---) \mathrm{p}<0.15$ 
between Great South Channel right whale SPUE and C. finmarchicus concentration from the Massachusetts Bay tract of the CPR.

Right whale SPUE was usually lower in the Great South Channel when the concentration of other copepods was higher in the western Gulf of Maine (Fig. 8b). During trimester 1 there was a weak negative association between the concentration of other copepods and right whale SPUE. During trimester 2 (late April to mid-August) the association was significant and negative $\left(r^{2}=0.51, p<0.05\right)$, and during trimester 3 right whale SPUE did not vary notably with the concentration of other copepods.

\section{DISCUSSION}

We found that regional-scale mean copepod concentration can be a good indicator of right whale SPUE in 2 right whale critical habitats. The association changes both in time and between habitats, with Calanus finmarchicus playing a more important role in the Great South Channel, and other copepods playing a more important role in Cape Cod Bay.

Wishner et al. (1995) found significantly higher abundances of stage C5 Calanus finmarchicus in areas where whales were present than in areas where they were absent. Baumgartner et al. (2003a) found a significant relationship between right whale sighting rate and $C$. finmarchicus abundance at the depth of the stage C5 C. finmarchicus diapausing layer (90 to $140 \mathrm{~m}$ ), but not with whole water-column abundances of $C$. finmarchicus. These studies emphasize the importance of subsurface aggregations of $C$. finmarchicus to feeding right whales and suggest that, due to spatial and temporal heterogeneity in copepod concentration, the regionalscale copepod concentration may not be important. Our results stand in contrast to this suggestion. We found that the regional-scale mean copepod concentration, when measured in near-surface waters and averaged across space (rather than depth), is significantly related to the relative abundance of right whales at certain times of year.

In light of Figs. $8 a$ \& $6 b$, and keeping in mind that right whales feed at depth as well as near the surface, we view mean copepod concentration as good proxy for the availability of dense copepods patches to right whales. The results presented here complement those of Wishner et al. (1995) and Baumgartner et al. (2003a), and others, by expanding the spatiotemporal scale of study and the number of samples (Table 1) under consideration.

\section{Cape Cod Bay}

From the end of January to late March there is a suggestive, but statistically insignificant, positive relation-
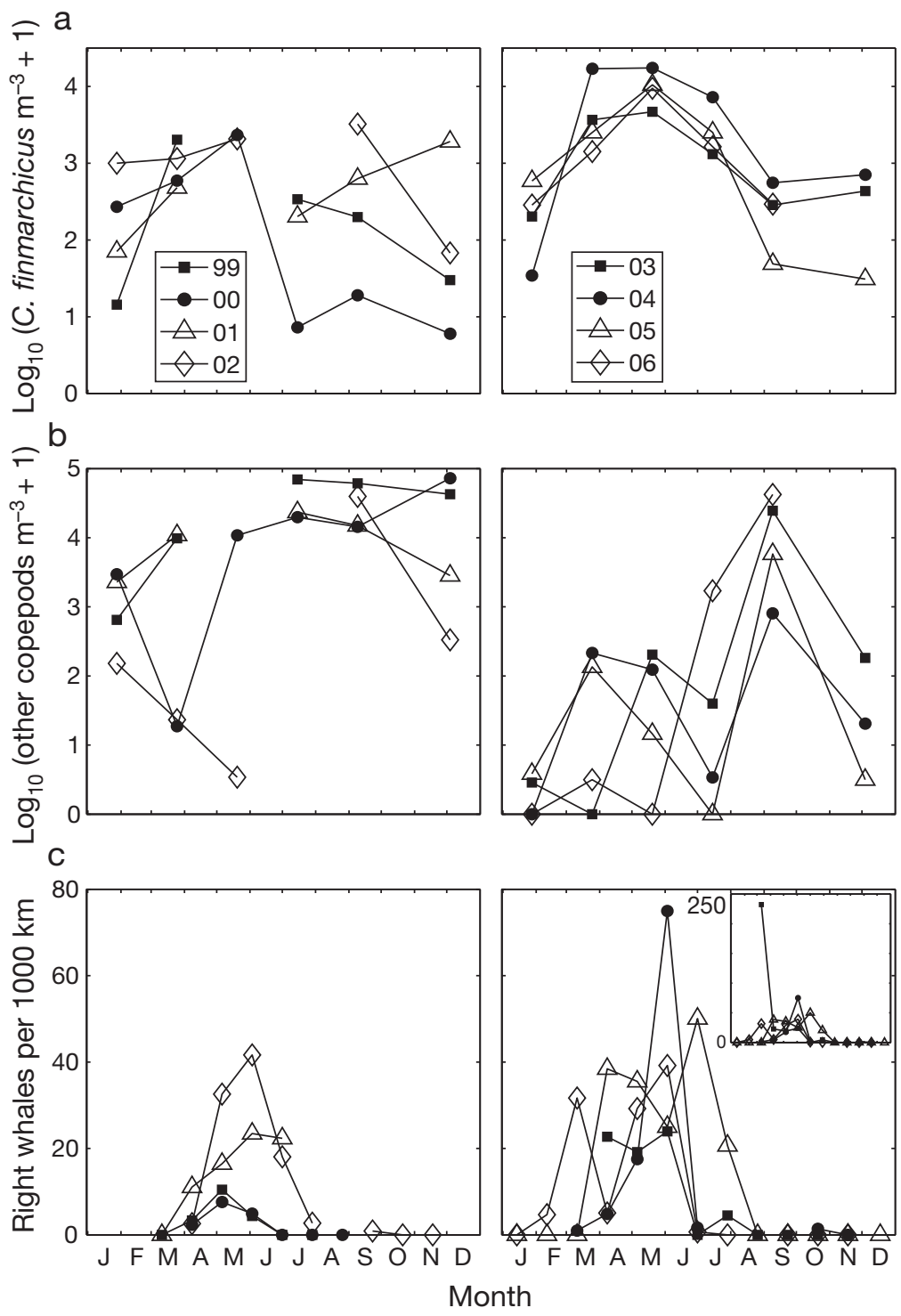

Fig. 7. Calanus finmarchicus, other copepods (Pseudocalanus spp. and Centropages typicus) and Eubalaena glacialis. Yearly time series (1999-2006) of (a) C. finmarchicus and (b) other copepods from the western Gulf of Maine tract of the CPR. (c) Right whale SPUE (whales per $1000 \mathrm{~km}$ of survey effort) in the Great South Channel. Inset shows right whale SPUE outlier from March 2003 
ship between the concentration of other copepods and right whale SPUE in Cape Cod Bay (Fig. 6b). Indeed, if right whales are feeding in Cape Cod Bay at this time of year, they could reasonably be expected to feed on the most abundant, available and acceptable copepods, which are the wintertime residents Pseudocalanus spp. and Centropages spp. (Fig. 5b). In contrast, there is a suggestive, though statistically insignificant, negative relationship between Calanus finmarchicus and right whale SPUE in the Bay during mid-winter (1-28 January) (Fig. 6a). This relationship, albeit weak, is surprising. The density of C. finmarchi-

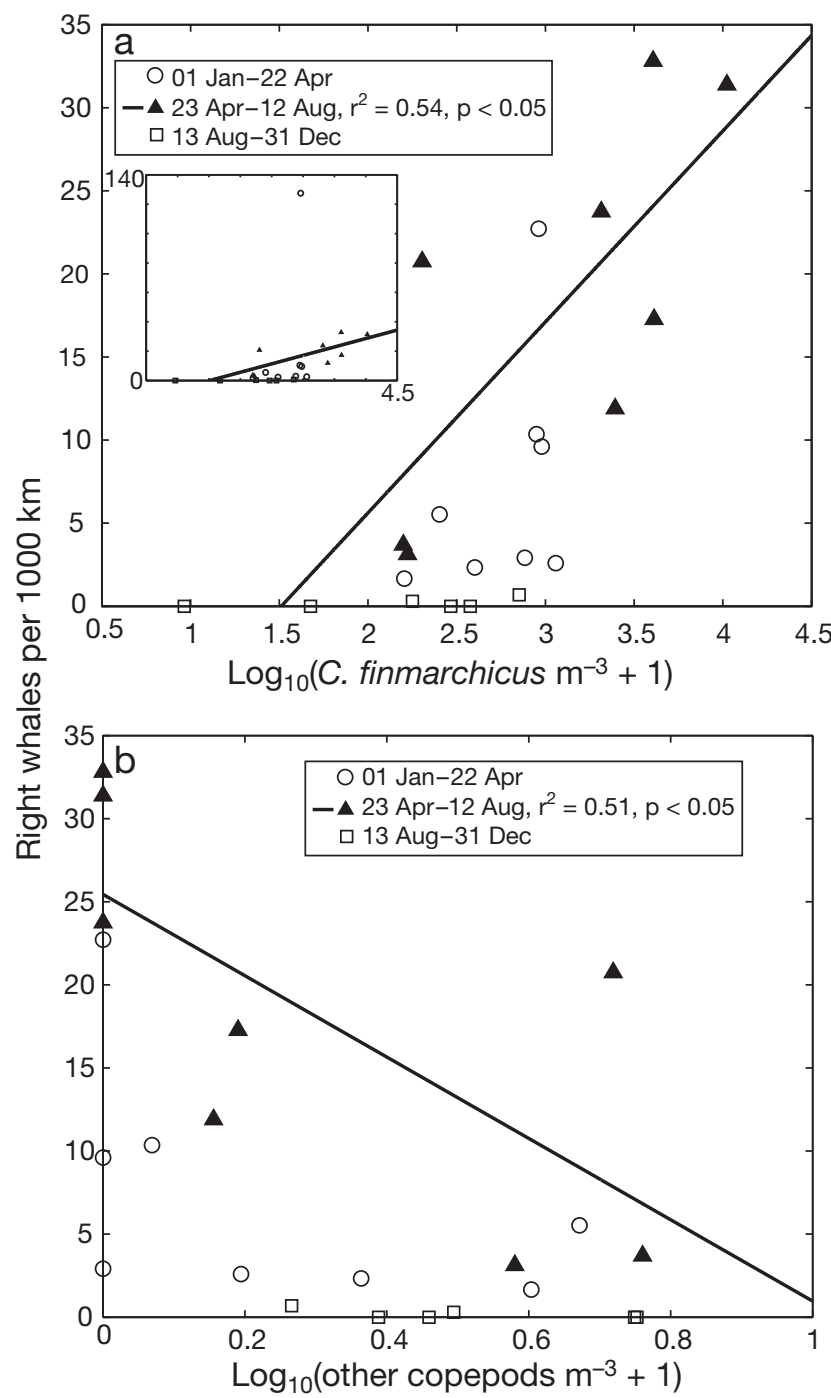

Fig. 8. Calanus finmarchicus, other copepods (Pseudocalanus spp. and Centropages typicus) and Eubalaena glacialis. Mean right whale SPUE (whales per $1000 \mathrm{~km}$ of survey effort) from the Great South Channel versus (a) C. finmarchicus and (b) other copepods from the western Gulf of Maine tract of the CPR during the following trimesters (1999-2006): 1 January-22 April (O), 23 April-12 August (A), 13 August-31 December $(\square)$. Inset shows a right whale SPUE outlier from March 2003 that was removed from the dataset cus is low and accounts for a small percentage of the overall copepod assemblage at that time of year, and we would not necessarily expect a strong relationship between $C$. finmarchicus and right whales (Fig. 2a). One hypothesis to explain this is that when $C$. finmarchicus are abundant in Cape Cod Bay, they are more abundant outside of the bay. This hypothesis is supported by the fact that $C$. finmarchicus arrive in Cape Cod Bay primarily via advection (DeLorenzo Costa et al. 2006, Jiang et al. 2007). Concentration of CPR-derived $C$. finmarchicus is generally higher in Massachusetts Bay (Fig. 2b) than in the western Gulf of Maine (Fig. 3a). A high C. finmarchicus concentration inside Cape Cod Bay may imply that conditions outside of the bay are more favorable for the production of C. finmarchicus. From our analysis, there appears to be no 'C. finmarchicus reason' for right whales to be in Cape Cod Bay prior to late March.

The maximum right whale SPUE value in Cape Cod Bay usually occurs in the early spring, during April. The same pattern was noted almost a century ago (Allen 1916). Typically, the concentration of other copepods has declined by this time of year, and the concentration of Calanus finmarchicus has increased to the point where they are on par with that of other copepods. The significant association between the concentration of other copepods and right whale SPUE in Cape Cod Bay at this time of year $\left(\mathrm{r}^{2}=0.53, \mathrm{p}<\right.$ 0.05), and the suggestive (but statistically insignificant) relationship between $C$. finmarchicus and right whale SPUE imply that the mean concentration of copepods in Cape Cod Bay is coupled to the number and quality of copepod patches in the bay, and thus the suitability of the bay for feeding right whales. These results are supported by the findings of Jiang et al. (2007) who found a significant relationship (using the criterion $\mathrm{p}<$ 0.10 ) between right whale SPUE and $C$. finmarchicus in Cape Cod Bay.

Despite the fact that right whales appear to respond more strongly to other copepods than to Calanus finmarchicus, we know that C. finmarchicus is an important part of the right whale's diet. Given this, why does the number of right whales in Cape Cod Bay decline just as $C$. finmarchicus concentration reaches the seasonal maximum value? Comparing apparent right whale departure and arrival times, inferred from SPUE values, in Cape Cod Bay and the Great South Channel, we see that as right whale SPUE declines in the bay, it increases in the channel (Figs. 2c \& 3b). This shift in the sighting frequency of right whales between the 2 neighboring habitats suggests that whales residing in Cape Cod Bay may move to the Great South Channel at this time. It is plausible that the relative concentration of $C$. finmarchicus and other copepods in neighboring habitats is responsible 
Table 2. Calanus finmarchicus, other copepods (Pseudocalanus spp. and Centropages spp.) and Eubalaena glacialis. Correlations between relative abundance of right whales (all parameter $y=$ right whale SPUE) and mean copepod concentration (parameter $x$ ) in Cape Cod Bay and the Great South Channel

\begin{tabular}{|lccrr|}
\hline Region & Parameter $x$ & $\mathrm{n}$ & $\mathrm{r}$ & $\mathrm{p}$ \\
\hline Cape Cod Bay & & & & \\
Calanus finmarchicus & 1 Jan-28 Jan & 8 & 0.61 & 0.11 \\
& 29 Jan-25 Feb & 8 & 0.42 & 0.31 \\
& 26 Feb-25 Mar & 8 & 0.44 & 0.27 \\
& 26 Mar-22 Apr & 8 & 0.59 & 0.12 \\
& 23 Apr-20 May & 8 & 0.06 & 0.89 \\
& 1 Jan-28 Jan & 8 & 0.07 & 0.85 \\
Other copepods & 29 Jan-25 Feb & 7 & 0.60 & 0.12 \\
& 26 Feb-25 Mar & 8 & 0.40 & 0.33 \\
& 26 Mar-22 Apr & $\mathbf{8}$ & $\mathbf{0 . 7 3}$ & $<\mathbf{0 . 0 5}$ \\
& 23 Apr-20 May & 8 & 0.01 & 0.98 \\
& & & & \\
Great South Channel & 1 Jan-22 Apr & 8 & 0.44 & 0.28 \\
Calanus finmarchicus & 23 Apr-12 Aug & $\mathbf{8}$ & $\mathbf{0 . 7 4}$ & $<\mathbf{0 . 0 5}$ \\
& 13 Aug-31 Dec & 6 & 0.54 & 0.27 \\
1 Jan-22 Apr & 8 & -0.50 & 0.20 \\
Other copepods & 23 Apr-12 Aug & $\mathbf{8}$ & $\mathbf{- 0 . 7 1}$ & $<\mathbf{0 . 0 5}$ \\
& 13 Aug-31 Dec & 6 & -0.65 & 0.22 \\
& & & & \\
& & &
\end{tabular}

for shifts in the relative abundance of right whales from Cape Cod Bay to the Great South Channel, and to other habitats.

If the highest Gulf of Maine Calanus finmarchicus abundance occurs over Wilkinson and Jordan Basins, and the lowest $C$. finmarchicus abundances occur in the waters of Massachusetts Bay and Cape Cod during January and February, as Meise \& O'Reilly (1996) reported, why is Cape Cod Bay utilized by right whales during this time of year? One possible explanation for the late winter occurrence of right whales in Cape Cod Bay is that the bay may preferentially attract demographic subsets of the North Atlantic right whale population. A few studies have explored the hypothesis that there is regional segregation of demographic groups in the North Atlantic right whale population, and there are a few examples of sighting heterogeneity related to life history stage. Brown et al. (2001) found lower identification rates for adult female right whales than for male and female juveniles and adult males. Weinrich et al. (2000) found longer residence times for mother-calf pairs than for other demographic groups in the Jeffrey's Ledge habitat, and Hamilton \& Mayo (1990) found that mothers with calves were not sighted in Massachusetts and Cape Cod Bays until after the first week of April. Further analysis of individually identified right whales and their inter- and intraannual sightings is needed to describe and assess the influence of right whale demography on their pattern of habitat use.

\section{Great South Channel}

Our interannual analysis showed that from late April to early August, region-wide mean concentration of Calanus finmarchicus was a strong indicator $\left(\mathrm{r}^{2}=0.54, \mathrm{p}<0.05\right)$ of right whale SPUE in the Great South Channel. Earlier in the year there was a positive relationship between $C$. finmarchicus and right whale SPUE in the channel, and later in the year there was no detectable relationship between $C$. finmarchicus and right whale SPUE in the channel. Overall, above average $C$. finmarchicus concentration appears to be a necessary condition for high relative abundance of right whales.

We have the most confidence in the result for late April to early August (Fig. 8a, $\boldsymbol{\Delta})$, since right whale survey effort in the Great South Channel was usually greatest at that time of year. If feeding is one of the primary reasons that right whales visit the Great South Channel, then the significant association between Calanus finmarchicus concentration and right whale sighting frequency in this region could be interpreted as an association between region-wide mean C. finmarchicus concentration and the number and quality of highdensity $C$. finmarchicus patches in the region.

In the Bay of Fundy, Baumgartner et al. (2003b) found that the average water-column concentration of stage C5 Calanus finmarchicus was lower in 2000 than in 2001, yet discrete layers of $C$. finmarchicus at depth had a higher concentration in 2000 than in 2001. This mismatch suggests that, at the scale of their study (on the order of $50 \mathrm{~km}^{2}$ and over several days during summer), the density of $C$. finmarchicus patches is not strongly coupled to regional-scale mean C. finmarchicus concentration. A critical difference between the study of Baumgartner et al. (2003b) and the present study is the temporal range considered (a few days versus months), and the copepod concentration averaging method (water-column averages versus surface spatial averages). Assuming whales require highdensity $C$. finmarchicus patches, the present study suggests that at the spatial scale of the Great South Channel and on a temporal scale of $4 \mathrm{mo}$, the number and frequency of patches increases with the regionalscale mean $C$. finmarchicus concentration.

\section{CONCLUSIONS}

Our interannual analysis showed that at certain times of year, the regional-scale mean copepod con- 
centration is an indicator of the relative abundance of right whales in 2 critical habitat areas. During early spring in Cape Cod Bay, there is a significant association between right whale SPUE and the concentration of other copepods (Pseudocalanus spp. and Centropages spp.). The relationship between Calanus finmarchicus and right whale SPUE in the Bay appears to be positive, but it is not statistically significant. The concentration of $C$. finmarchicus in the western Gulf of Maine, an acceptable proxy for the concentration of C. finmarchicus in the Great South Channel, is a significant indicator of right whale SPUE in the Great South Channel between late April and mid-August. It appears that use of the Great South Channel by right whales is substantially reduced when the concentration of C. finmarchicus is low. In general, C. finmarchicus is a conservative indicator of the right whale SPUE in the Great South Channel. Results from our analysis of interannual variability suggest that with seasonal dependence, (1) regional-scale mean copepod concentration is positively correlated to the relative abundance of right whales, and (2) models that forecast copepod concentration on a regional-scale could be useful for predicting where and when right whales are likely to be, and could therefore be useful tools for mitigating anthropogenic risk to North Atlantic right whales.

Acknowledgements. We thank D. J. Osterberg and M. K. Bessinger for collecting and organizing the Cape Cod Bay zooplankton data, and J. W. Jossi for providing the MARMAP and CPR data. We also thank the multitude of people who have participated in right whale surveys. This work has benefited from discussions with members of the New England Aquarium's Right Whale Research team, in particular P. K. Hamilton, A. R. Knowlton, Y. Guibault, M. K. Marx and S. D. Kraus. We thank P. J. Sullivan for encouragement and for helpful comments. This work was supported by NOAA's Right Whale Grants Program, NASA's Applied Science Program, and NSF's Information Technology Research Program. Management of the NARWC database was supported through the URI-NOAA Cooperative Marine Education and Research Program.

\section{LITERATURE CITED}

Allen GM (1916) The whalebone whales of New England. Mem Boston Soc Nat Hist 8:107-322

Baumgartner MF, Mate BR (2003) Summertime foraging ecology of North Atlantic right whales. Mar Ecol Prog Ser 264:123-135

Baumgartner MF, Cole TVN, Campbell RG, Teegarden GJ, Durbin EG (2003a) Associations between North Atlantic right whales and their prey, Calanus finmarchicus, over diel and tidal time scales. Mar Ecol Prog Ser 264:155-166

Baumgartner MF, Cole TVN, Clapham PJ, Mate BR (2003b) North Atlantic right whale habitat in the lower Bay of Fundy and on the SW Scotian Shelf during 1999-2001. Mar Ecol Prog Ser 264:137-154
Baumgartner MF, Mayo CA, Kenney RD (2007) Enormous carnivores, microscopic food, and a restaurant that's hard to find. In: Kraus SD, Rolland RM (eds) The urban whale: North Atlantic right whales at the crossroads. Harvard University Press, Cambridge, MA, p 138-171

Beardsley RC, Epstein AW, Chen C, Wishner KF, Macaulay MC, Kenney RD (1996) Spatial variability in zooplankton abundance near feeding right whales in the Great South Channel. Deep-Sea Res II 43:1601-1625

Brown MW, Brault S, Hamilton PK, Kenney RD and others (2001) Sighting heterogeneity of right whales in the western North Atlantic: 1980-1992. J Cetacean Res Manag Spec Issue 2:245-250

Brown MW, Kraus SD, Slay CK, Garrison LP (2007) Surveying for discovery, science, and management. In: Kraus SD, Rolland RM (eds) The urban whale: North Atlantic right whales at the crossroads. Harvard University Press, Cambridge, MA, p 105-137

CETAP (Cetacean and Turtle Assessment Program) (1982) A characterization of marine mammals and turtles in the mid-and North-Atlantic areas of the U.S. outer continental shelf. Final report, contract no. AA551-CT8-48, Bureau of Land Management, Washington, DC

> Chen C, Beardsley RC, Limeburner R (1995) Variability of currents in late spring in the northern Great South Channel. Cont Shelf Res 15:451-473

Clapham PJ, Young SB, Brownell RL Jr (1999) Baleen whales: conservation issues and the status of the most endangered populations. Mammal Rev 29:37-62

Cole TVN, Gerrior P, Merrick RL (2007) Methodologies and preliminary results of the NOAA National Marine Fisheries Service aerial survey program for right whales (Eubalaena glacialis) in the northeast U.S., 1998-2006. Northeast Fish Sci Cent Ref Doc 07-02. National Marine Fisheries Service, Woods Hole, MA

DeLorenzo Costa A, Durbin EG, Mayo CA, Lyman EG (2006) Environmental factors affecting zooplankton in Cape Cod Bay: implications for right whale dynamics. Mar Ecol Prog Ser 323:281-298

DoN (Department of the Navy) (2005) Marine resources assessment for the northeast operating areas: Atlantic City, Narragansett Bay, and Boston. Tech Rep, contract no. N62470-02-D-9997, task order no. 0018. Naval Facilities Engineering Command, Norfolk, VA

> Durbin EG, Garrahan PR, Casas MC (2000) Abundance and distribution of Calanus finmarchicus on Georges Bank during 1995 and 1996. ICES J Mar Sci 57:1664-1685

Gaskin DE (1982) The ecology of whales and dolphins. Heinemann Educational Books, Portsmouth, NH

> Greene CH, Pershing AJ (2000) The response of Calanus finmarchicus populations to climate variability in the Northwest Atlantic: basin-scale forcing associated with the North Atlantic Oscillation (NAO). ICES J Mar Sci 57: 1536-1544

Greene CH, Pershing AJ (2004) Climate and the conservation biology of North Atlantic right whales: The right whale at the wrong time? Front Ecol Environ 2:29-34

Hain JHW, Ratnaswamy MJ, Kenney RD, Winn HE (1992) The fin whale, Balaenoptera physalus, in waters of the northeastern United States continental shelf. Rep Int Whal Comm 42:653-669

Hamilton PK, Mayo CA (1990) Population characteristics of right whales (Eubalaena glacialis) observed in Cape Cod and Massachusetts Bays, 1978-1986. Rep Int Whal Comm Spec Issue 12:203-208

> Jiang M, Brown MW, Turner JT, Kenney RD, Mayo CA, Zhang Z, Zhou M (2007) Springtime transport and reten- 
tion of Calanus finmarchicus in Massachusetts and Cape Cod Bays, USA, and implications for right whale foraging. Mar Ecol Prog Ser 349:183-197

> Jossi JW, Goulet J (1993) Zooplankton trends: US northeast shelf ecosystem and adjacent regions differ from northeast Atlantic and North Sea. ICES J Mar Sci 50:303-313

Kane J (2005) The demography of Calanus finmarchicus (Copepoda: Calanoida) in the middle Atlantic bight, USA, 1977-2001. J Plankton Res 27:401-414

Kenney RD (1990) Bottlenose dolphins off the northeastern United States. In: Leatherwood S, Reeves RR (eds) The bottlenose dolphin. Academic Press, San Diego, CA, p 369-386

Kenney RD (2001) Anomalous 1992 spring and summer right whale (Eubalaena glacialis) distributions in the Gulf of Maine. J Cetacean Res Manag Spec Issue 2:209-223

Kenney RD, Winn HE (1986a) Aerial surveys of right whales in the Great South Channel, spring 1986. Final report, order no. 12504. Minerals Management Service, Washington, DC

Kenney RD, Winn HE (1986b) Cetacean high-use habitats of the northeast United States continental shelf. Fish Bull (Wash DC) 84:345-357

Kenney RD, Winn HE (1987) Aerial surveys of right whales in the Great South Channel, spring 1987. Final report, order no. 14624. Minerals Management Service, Washington, DC

Kenney RD, Wishner KF (1995) The South Channel Ocean Productivity EXperiment. Cont Shelf Res 15:373-384

Kenney RD, Hyman MAM, Owen RE, Scott GP, Winn HE (1986a) Estimation of prey densities required by western North Atlantic right whales. Mar Mamm Sci 2:1-13

Kenney RD, Winn HE, Brown CW (1986b) Aerial surveys for right whales in the Great South Channel, spring 1985. Final report, Contract no. NA-84-EA-C-00079. National Marine Fisheries Service, Woods Hole, MA

Kenney RD, Winn HE, Macaulay MC (1995) Cetaceans in the Great South Channel, 1979-1989: right whale (Eubalaena glacialis). Cont Shelf Res 15:385-414

Kenney RD, Mayo CA, Winn HE (2001) Migration and foraging strategies at varying spatial scales in western North Atlantic right whales. J Cetacean Res Manag Spec Issue 2:251-260

Kraus SD, Kenney RD, Knowlton AR, Ciano JN (1993) Endangered right whales of the southwestern North Atlantic. Final report, contract no. 14-35-0001-30486. Minerals Management Service, Herndon, VA

Lynch DR, Gentleman WC, McGillicuddy DJ Jr, Davis CS (1998) Biological/physical simulations of Calanus finmarchicus population dynamics in the Gulf of Maine. Mar Ecol Prog Ser 169:189-210

Mayo CA, Marx MK (1990) Surface foraging behavior of the North Atlantic right whale, Eubalaena glacialis, and associated zooplankton characteristics. Can J Zool 68: 2214-2220

Mayo CA, Letcher BH, Scott S (2001) Zooplankton filtering efficiency of the baleen of a North Atlantic right whale, Eubalaena glacialis. J Cetacean Res Manag Spec Issue 2: 225-229

Mayo CA, Nichols OC, Bessinger MK, Brown MW, Marx MK, Browning CL (2004) Surveillance, monitoring, and management of North Atlantic right whales in Cape Cod Bay and adjacent waters-2004. Final report submitted to the Commonwealth of Massachusetts, Division of Marine Fisheries. Center for Coastal Studies, Provincetown, MA

Editorial responsibility: Peter Verity, Savannah, Georgia, USA
Meise CJ, O'Reilly JE (1996) Spatial and seasonal patterns in abundance and age composition of Calanus finmarchicus in the Gulf of Maine and on Georges Bank 1977-1987. Deep-Sea Res II 43:1473-1501

MERCINA (Marine Ecosystem Responses to Climate in the North Atlantic) (2001) Oceanographic responses to climate in the Northwest Atlantic. Oceanography 14: $76-82$

Murison LD, Gaskin DE (1989) The distribution of right whales in the Bay of Fundy, Canada. Can J Zool 67: $1411-1420$

Pershing AJ, Greene CH, Jossi JW, O'Brien L, Brodziak JKT, Bailey BA (2005) Interdecadal variability in the Gulf of Maine zooplankton community, with potential impacts on fish recruitment. ICES J Mar Sci 62:1511-1523

Pittman S, Costa B, Moy C, Wiley D, Kenney RD (2006) Cetacean distribution and diversity. In: Battista T, Clark R, Pittman S (eds) An ecological characterization of the Stellwagen Bank National Marine Sanctuary Region: oceanographic, biogeographic, and contaminants assessment. NOAA Tech Mem NCCOS 45. Center for Coastal Monitoring and Assessment, NOAA National Centers for Coastal Ocean Science, Silver Spring, MD, p 265-326

Posgay JA, Marak RR (1980) The MARMAP bongo zooplankton samplers. J Northwest Atl Fish Sci 1:91-99

Right Whale Consortium (2007) North Atlantic Right Whale Consortium Sightings Database 08/23/2007. New England Aquarium, Boston, MA

Shoop CR, Kenney RD (1992) Seasonal distributions and abundances of loggerhead and leatherback sea turtles in waters of the northeastern United States. Herpetological Monogr 6:43-67

Sibunka J, Silverman MJ (1984) MARMAP surveys of the continental shelf form Cape Hatteras, North Carolina, to Cape Sable Nova Scotia (1977-1983). Atlas no. 1. Summary of operations. NOAA Tech Mem NMFS-F/NEC-33

Sibunka J, Silverman MJ (1989) MARMAP surveys of the continental shelf form Cape Hatteras, North Carolina, to Cape Sable Nova Scotia (1984-1987). Atlas no. 3. Summary of operations. NOAA Tech Mem NMFS-F/NEC683

> Warner AJ, Hays GC (1994) Sampling by the continuous plankton recorder survey. Prog Oceanogr 34:237-256

Watkins A, Schevill WE (1976) Right whale feeding and baleen rattle. J Mammal 57:58-66

Weinrich MT, Kenney RD, Hamilton PK (2000) Right whales (Eubalaena glacialis) on Jeffrey's Ledge: A habitat of unrecognized importance? Mar Mamm Sci 16:326-337

Winn HE, Scott EA, Kenney RD (1985) Aerial surveys for right whales in the Great South Channel, spring 1984. Report no. MMC-84/04. US Marine Mammal Commission, Washington, DC

Winn HE, Price CA, Sorensen PW (1986) The distributional biology of the right whale (Eubalaena glacialis) in the western North Atlantic. Rep Int Whal Comm Spec Issue 10:129-138

Wishner KF, Durbin EG, Durbin A, Macaulay MC, Winn HE, Kenney RD (1988) Copepod patches and right whales in the Great South Channel off New England. Bull Mar Sci 43:825-844

Wishner KF, Schoenherr JR, Beardsley R, Chen C (1995) Abundance, distribution and population structure of the copepod Calanus finmarchicus in a springtime right whale feeding area in the southwestern Gulf of Maine. Cont Shelf Res 15:475-507

Submitted: March 20, 2008; Accepted: November 15, 2008 Proofs received from author(s): February 18, 2009 